\title{
The Impact of Native American Activity on Vegetation and Soil Charcoal in the Eastern US
}

\author{
Johnson Sarah E and Abrams Marc D* \\ Department of Ecosystem Science and Management, Pennsylvania State University, USA
}

Submission: February 01, 2017; Published: March 20, 2017

*Corresponding author: Abrams Marc D, Department of Ecosystem Science and Management, Pennsylvania State University, USA, Email: agl@psu.edu

\begin{abstract}
This research was conducted to ascertain whether areas of cultural resources where significant Native American activity has occurred during the Late Woodland and Mississippian Time Periods can be identified through the dominant vegetation composition and soil features of the present-day landscape. A general hypothesis is that Native Americans left a legacy of their land uses in the present-day ecosystem by propagating certain important wild plant species and crop species in the forest, known as "indicator species", as well as the presence of soil charcoal from past fire activity. Present-day forest ecosystems in eastern Virginia and northern New York contained many Native American indicator species and buried soil charcoal. Pinpointing a combination of geological, soil, topographical and vegetation characteristics that are typical of Late Woodland and Mississippian Time Period Native American cultural sites could allow Cultural Resources Managers to more efficiently identify landscapes where the probability of locating archaeological features is greater. Analysis of these features may also allow personnel to more accurately characterize the types of land use or activities that occurred on these sites. Soil charcoal analysis could serve as a rapid method of determining fire history during the time period of interest. Surveys of vegetation could be integrated into testing strategies either before or after archaeological site discovery, to both locate landscapes of particular interest, or further elucidate what kinds of activities may have been occurring following the discovery of a site.
\end{abstract}

\section{Introduction}

Significant alteration in forest composition and structure took place throughout the time since the first natives inhabited eastern North America, around 12,000 years ago [1,2]. Estimates of Native American impacts on forests range from landscape scale [3-6] to the local level (not extending far beyond major population centers) [7,8]. Soils may also have been impacted, both intentionally through amendments, and unintentionally through burning and midden creation [9-11]. In areas such as Crawford Lake, Ontario, paleoecologists studying pollen records have noted a transition from northern hardwood-dominated to oak-pine forests types coincident with Native American habitation (1300s to 1400s) [12]. This shift to dominance of fire disturbance (indicated by a preponderance of charcoal accumulated during this time period) and fire-adapted tree species suggests that Native American burning drove changes in forest composition across a broad landscape. Delcourt et al. [13] document significant alteration in forest composition around 3000 B.P. in Kentucky, and attribute it to Native American clearing for cultivation of native plants and broadcast understory burning.
Native Americans in the eastern woodlands of North America used the forest for a wide variety of purposes and products, for food, medicinal, material, and ceremonial uses [3,6,14]. Native Americans utilized specific vegetation species in their diet, depending on season, climate, and proximity to fresh, brackish, or saltwater [15]. During the Late Woodland Time Period (beginning 1600 B.P. in northeastern North America), Native American groups in the eastern United States were primarily hunter-gatherers [16-19], and used protoagricultural methods to cultivate semi-domesticated varieties of several native plant species [20]. The transition to the Mississippian Time Period (around 1000 years before present, depending on location) was typified by the adoption of maize-based agricultural methods, however hunting and gathering continued to be very important. Land-uses included the frequent burning of the forest understory, protection and transportation of important species of plants (Kentucky coffee tree (Gymnocladus dioicus), paw paw (Asimina triloba) $[3,21]$, girdling trees surrounding important mast-producers [22-24], and cultivation of semi-domesticated varieties of wild plants $[14,6]$. Other land uses, such as clearing 
and burning for the creation of village and camp sites and agricultural fields, indirectly promoted disturbance-adapted species, maybe of which were important in the diet of Native Americans (e.g., walnut (Juglans spp), oak (Quercus spp) and other mast-producers, and blueberry (Vaccinium spp) and other berry-producing shrubs) $[3,8,25,26]$.

Burning of the forest understory was a common and longterm practice of Native American groups, as evidenced by historic records andaccounts, archaeologicalartifacts, and paleoecological charcoal and fire scar studies [6,12,16,27-31]. Researchers have reported very frequent pre-European settlement fire return rates [32]. In the northeast, where lightening ignitions (the only source of natural ignition) are relatively infrequent [33,34], this indicates the significant influence of Native American ignitions. In eastern North America during the time period of interest to this study, understory burning facilitated travel, improved visibility in the forest, increased browse for game, increased berry and mast production, and was used to clear agricultural fields and improve hunting $[1,3,35]$. The prevalence of burning perpetuated mostly mid- and early successional tree species that are adapted to disturbances, particularly fire. This includes oak and hickory (Carya spp) species, as well as others that are adapted to reproduce quickly in highly disturbed and high light conditions $[25,36,37]$. Characteristics of oaks that allow them to be so well adapted to fire and other disturbances are thick bark, resprouting ability, high root to shoot ratios of growth, and the ability to compartmentalize wounds [30,38,39].

Active fostering of woody fruit and mast species may also have been practiced by many Native American groups. For example, the Susquehannocks and Iroquois planted black walnut (J. nigra) and hickory in New York $[8,22]$. In the Midwest, trees surrounding hickory were girdled to increase available resources and thus, mast production $[22,23]$. This is compelling evidence of the early use of silvicultural techniques by Native Americans $[8,26]$. Other plant species may have been saved and transported when groups moved such as Kentucky coffee tree, American chestnut (Castanea dentata), Canada plum (Prunus nigra), groundnut (Apios americana), and leek (Allium porrum), although historical evidence for this is lacking and it must be confirmed through archaeobotanical testing [3,14]. Native Americans in the northeastern region of the United States maintained berry patches for food and attraction of game species such as bear and deer [3,6,28]. "Mast orchards" of oak and hickory may have been maintained for the same reasons $[6,22]$. These patches may have been located near villages and sites of occupation for practical reasons.

Native American agriculture was important during this time in prehistory, and several native plant species were cultivated, prior to the introduction of subtropical crops such as maize (Zea mays), beans (Phaseolus vulgaris), and subtropical squash varieties (Cucurbita spp) $[9,40]$. The eastern United States, in fact, is believed to be the center of domestication for four wild plants, referred to as the Eastern Agricultural Complex (EAC): marshelder (Iva annua), chenopod (Chenopodium berlandieri), squash (C. pepo), and sunflower (Helianthus annuus), indicating both the importance of agriculture in Native American life and the technological advancement in agriculture that these groups of people were capable of $[14,20,41]$. The cultivation of these species, using early methods of agriculture such as raised bed technology, included evolution through selection of varieties for various characteristics such as seed size [20]. Storage of seeds of these species was practiced throughout the harvest season, in pits dug in the ground and lined with tree bark [42,43]. Some of these species are still present on the landscape today, such as chenopodium or lambsquarters (C. album), a variety of the native cultigen, in the northeastern United States.

Vegetation species of high importance to Native Americans can be identified through ethnobotanical research. Distribution and concentration of certain plant species on the landscape, both past and present, may indicate the location of cultural resources, and where Native Americans were active in their land uses such as burning, cultivation, and collection and storage of food such as grains and seeds. Catchment analysis of species important in the ethnobotanical record has reported significant anthropological activity in the landscape of eastern North America [8,26]. Marks, Gardescu, and Seischab [44] identified old Native American clearings and reported oak, hickory, and pine (Pinus spp) growing in areas previously inhabited by peoples of the Iroquois Confederacy in central New York. Whitney and DeCant [45] suggested that Iroquois may be associated with oakchestnut forests in their witness tree study across northwestern Pennsylvania, including the Allegheny Plateau. Additional research supports the high incidence of important mastproducing and disturbance adapted species on sites previously inhabited by Native Americans [8,27,31].

Evidence suggests that land use legacies and vegetation species propagated by Native Americans still exist on presentday landscapes. Post-European settlement land uses perpetuated this vegetation composition in many areas, making it possible to discern the effect of centuries of Native American occupation in the present-day forest [25]. Significant land use by European settlers occurred at varying times throughout eastern North America, falling around the early 1700s in northern New York [46], and early 1600s in coastal Virginia [47]. European settlers would have initiated clearing of forests in much the same way as Native Americans did, for both single and several-family settlements on the frontier [48]. However the pace and extent of forest clearing has accelerated over time $[49,50]$. These land uses would have served to continue the dominance of and even expand the disturbance-adapted species that were already prevalent in the forest due to Native American land uses, such as oak, hickory, pine, and old-field herbaceous species, such as chenopodium. 
The overarching objective of this research is to ascertain if areas of cultural resources where significant Native American activity has occurred during the Late Woodland and Mississippian Time Periods can be identified through the dominant vegetation composition and soil features of the present-day landscape. A general hypothesis is that Native Americans left a legacy of their land uses in the present-day ecosystem by propagating certain important wild plant species and crop species in the forest, known as "indicator species". Study of indicator species is based on the idea that the presence and number of certain plant species, including trees, shrubs, and herbs, can be an indicator of preferential utilization by Native Americans. Indicator species are discernible in the ethnobotanical record because of their prevalence in the Native diet and because the plant parts utilized (and thus gathered, cached, and transported) included the seed or seed coat of the plant.

\section{Objectives}

a) Identify indicator species characteristic of each study area based on Native American dietary, medicinal, material, and ceremonial plant species and land uses.

b) Determine the current vegetation that is characteristic of archaeological sites and off-site areas.

c) Determine if individual indicator species, or aggregated groups of indicator species (e.g., total mast species importance), can predict the presence of cultural resources.

d) Determine if soil charcoal presence can be used to predict the location of archaeological sites.

\section{Methods}

In 2008-2010, ethnobotanical literature review was undertaken for the areas of Fort Drum, MCB Quantico, and the Cheatham Annex. Literature was reviewed to locate potential indicator species of Native American activity, and included journal articles, conversations with cultural resources management personnel, archival data, and field reconnaissance of important archaeological sites of known habitation type and length. In particular, species of importance in the diet of the Native Americans were considered to have strong potential as indicators.

During the months of June-August of 2008 through 2010, each study area was visited multiple times for vegetation survey and soil charcoal analysis of cultural sites and associated noncultural, off-site areas. Cultural sites at each military installation have been located by Cultural Resources Management (CRM) teams, and archaeological excavations have identified the boundary of each site, the potential use of each site, and the time period the site was inhabited. Sites with clear boundaries, minimal disturbance of on-site vegetation, and inhabited in the Late Woodland and Mississippian time periods were chosen for survey. Off-site areas were chosen in association with each surveyed cultural site (where possible). These sites were paired with surveyed cultural sites, and located adjacent to the cultural site on the same landform, to control for soil type, geology, topography, and land-use history. Off-site areas were difficult to find in some cases because, on military-owned lands, archaeological testing is conducted much of the time because military engineers would like to construct buildings or training sites in a certain area. If cultural resources are located by the testing, the area of the site is protected from military activities; however, any surrounding areas that test negatively are free to be used for military activities. The vast majority of the time, these activities involve at least extensive clearing and ground disturbance, if not construction of buildings and impermeable surfaces.

At Fort Drum, New York, 16 archaeological sites were available for survey (50 plots total), and 8 off-site areas were able to be located (25 plots total). At MCB Quantico, Virginia, 9 archaeological sites were surveyed (28 plots total), and 5 paired off-site areas were able to be located (20 plots total). In the Wilderness Area on the Cheatham Annex, Virginia, only a small portion of the land had been tested for archaeological resources. It was tested because it was in the "footprint" of a planned boat launch for recreational purposes. All the shovel test pits that were put in were positive for artifacts. Three separate Late Woodland sites were identified within this tested portion of the Wilderness Area, although no further archaeological testing was conducted. These sites were surveyed for vegetation composition in conjunction with 2 outside of the Wilderness Area, for a total of 5 confirmed archaeological sites (20 plots total). Along the bank of the creek where the boat launch was planned, shell midden evidence was found in abundance in several areas, and is considered diagnostic of Native American habitation and influence [51] (Bruce Larson, NAVFAC Mid Atlantic Cultural Resources, personal communication). The same shell midden evidence was also present further along the creek bank to the southwest of the tested area. Areas where shell midden evidence were located, but had not been tested for archaeological resources using traditional methods, were surveyed using the same methods as for all other known archaeological sites and off-site areas ( 7 sites, for a total of 23 plots surveyed). The sites identified through shell midden evidence were considered archaeological sites even though they have not been officially tested using shovel test pits. Because of the lack of traditional testing and development that has occurred outside of the Wilderness Area, no paired off-site areas were able to be located.

Within the CRM-designated boundaries of each cultural site, stratified circular fixed-area vegetation plots were set on transects with a bearing dictated by the shape and spatial orientation of the cultural site. Generally, plot centers were ten meters apart, although in some sites, size and shape of the cultural site precluded such regularity. Overstory trees were identified to species and diameter as breast height (dbh) was 
recorded in an $800 \mathrm{ft}^{2}\left(74.3 \mathrm{~m}^{2}\right)$ plot. Small tree species (such as serviceberry, Amelanchier spp, and paw paw) were identified and counted in a $100 \mathrm{ft}^{2}\left(9.3 \mathrm{~m}^{2}\right)$ plot, and herbaceous and shrub species were quantified in a $50 \mathrm{ft}^{2}\left(4.6 \mathrm{~m}^{2}\right)$ plot. Herbaceous species, shrubs, and vines were given a cover class percentage within the $50 \mathrm{ft}^{2}$ plot $(0-5 \%, 5.1-25 \%, 25.1-50 \%, 50.1-75 \%$, $75.1-95 \%, 95.1-100 \%)$, or simply recorded as present within each plot.

Soil charcoal samples to the depth of Native American occupation were taken at each vegetation plot center. The depth to Native American occupation was determined through consultation with Cultural Resources Management personnel. At Fort Drum, this depth is $\sim 20 \mathrm{~cm}$; slower decomposition in this relatively cold climate area inhibits soil buildup. At Quantico and the Cheatham Annex this depth is $\sim 30 \mathrm{~cm}$. When each sample was taken, the top $10 \mathrm{~cm}$ of soil and the organic layer were removed. These samples were taken with a hand trowel or soil corer, contained in plastic bags, and transported back to a lab. In the lab, samples were spread on a surface to dry, and thoroughly searched for coarse soil charcoal, defined as charcoal pieces greater than $2 \mathrm{~mm}$ in dimension (length or width) [5254]. Coarse soil charcoal is indicative of on-site fire, and is distinguished from fine soil charcoal by size. Fine soil charcoal is defined as charcoal pieces $1.9 \mathrm{~mm}$ or less in dimension and could be deposited on site through wind action from outside sources. Thus, fine soil charcoal cannot be assumed to have originated in a fire on that location. Soil charcoal samples were determined to be either positive or negative for coarse charcoal.

Data collected on overstory individuals of tree species were analyzed for frequency, density, dominance, relative frequency, relative density, relative dominance, and relative importance value. The frequency for each tree species is expressed as the number of plots in which overstory individuals of that species occurred. The density of each tree species is the number of overstory individuals of that species found in all plots. Density is then scaled up to the number of trees per hectare of each species. Dominance is expressed as the total basal area for overstory individuals of each tree species across all plots, and is also scaled up to basal area $\left(\mathrm{m}^{2}\right)$ per hectare. Then the relative indices were calculated by dividing each value for each individual species by the column total. Finally, a relative importance value was calculated for each species by adding the relative frequency, relative density, and relative dominance for each tree species and dividing that number by three.

Analyzing data at the individual site level was somewhat confounded by low plot numbers at some sites due to archaeological site size, and the lack of directly paired off-site areas for some archaeological sites. Therefore individual sitelevel data were aggregated across archaeological sites and off-site areas among each military base, using individual plots as replicates (importance values were calculated for each plot and archaeological and off-site plot averages were compared).
Importance values were calculated on a species by species basis across all archaeological sites versus off-site areas, as well as for shell midden sites on the Cheatham Annex. At Fort Drum and Quantico, overstory tree importance data was compared between archaeological sites and off-site areas. At the Cheatham Annex, data was compared between archaeological sites discovered using traditional testing methods, and archaeological sites discovered through identification of shell midden evidence in the soil. Because of the lack of off-site areas for comparison, and classification of all sites as archaeological sites, the sites discovered using the two different methods were compared to note differences in forest composition. This comparison will allow determination of our ability to discern the location of archaeological sites using standard characteristics of forest composition such as prevalent species and/or presence of indicator species. Thus, if the same composition is noted between these two site types, the overstory composition could be considered typical of archaeological sites. If data for a species was distributed normally and archaeological data and off-site data displayed equal variance, a Student's t-test was performed. If assumptions of normality and equal variance were not met, a more conservative Welch's t-test was performed. All tests were conducted in statistical program R [55].

To further elucidate patterns between archaeological and off-site areas, additional variables of interest not accounted for by traditional t-tests were incorporated (such as soils and soil charcoal, etc). Classification and regression tree models employing the Random Forest [56,57] algorithm were used to determine the importance of various species (presence/ absence and quantitative measures), suites of species, and other landscape level factors in predicting the presence of archaeological significance on a given site. Random Forest is an ensemble classifier statistical method, meaning that multiple models are used to identify to which of a set of categories each new observation, or the next observation, belongs. In the statistical package randomForest, if the response variable is a factor (categorical variable), classification trees are used. If the response variable is continuous, regression is used. Both involve a random subset of data that is used to build a model, or tree. To build each tree, a random sample is drawn from the original data set, and the values of a subset of the predictor variables are used to grow a classification or regression tree. The variable selection for each split in the tree (at what are known as nodes) is conducted from a small random subset of predictor variables (the number of variables to use is specified by the user; a subset of five of the predictor variables was used here). A userspecified number of trees are grown (1,000 trees were grown for each response), each with the randomly chosen subset of samples, and random selection of predictor variables. Each individual tree outputs a variable that it has found to be most able to predict the status of the response variable; each time a tree predicts a variable, it is considered a "vote" for that variable. From the complete forest the status of the response variable is 
predicted as an average or majority vote of the predictions of all trees. The data used to construct the trees are known as the "in bag" sample, while the unused data are known as the "out of bag" (oob) sample. To estimate the accuracy of the predictions of the trees, the out of bag sample is ran through each tree, and the difference in predicted importance of each variable from the initial growth of the tree and the growth of the tree with the oob sample is known as the oob error estimation.

The datasets for classification tree analysis were built with the following variables: Site Name (identifying name of the archaeological site or its off-site counterpart), Plot number, Treatment (archaeological or off-site), elevation, aspect (transformed into a linear variable using the formula 1- $\cos (($ aspect-30)*pi/180)), slope, soil series (excluding indicators of more specific characteristics such as slope), soil texture, presence/absence variables for all native species of any significance in the ethnobotanical record (i.e., species were included if they are native and generally edible, regardless of their significance in literature review), importance of indicator tree species (oak, hickory, and fruit-producing trees; by number of occurrences), importance of berry-producing indicator species (both tree and shrub species, by number of occurrences), total number of utilized species surveyed per plot, and presence of coarse soil charcoal in each plot. Using this dataset, classification tree models were ran using Treatment (archaeological or offsite) as the response variable, and all other variables were used as predictors in each model. These models were run for Fort Drum and MCB Quantico vegetation data to compare overall composition and characteristics of archaeological sites versus off-site areas.

Many characteristics of the archaeological sites were not easily quantifiable or testable through traditional survey and statistical methods. These include small catchments of particular species and overall site factors that were not quantified in the field, such as site openness. Qualitative and descriptive methods were used in the consideration of these site characteristics.

\section{Results \& Discussion}

Indicator species were identified for each area as a subset of all species utilized (Tables 1-3). To qualify as an indicator species of particular importance, there must be significant reference to the species in historic accounts as being important for the diet or important medicinally. Indicator species identified at Fort Drum included oak species, which are very important mastproducers (Table 1) [6]. Materials sources that were important are pine species, most notably pitch (P. rigida), white (P. strobus), and red pine ( $P$. resinosa). The proximity of this area to the Black River, an important thoroughfare, would indicate that dugout canoes would be used for transportation (Laurie Rush, Fort Drum CRM, personal communication). These canoes would be built from pine tree trunks [58]. Several of these tree species are also indicative of past disturbance regimes that promote fire-adapted, mid-successional species, most notably oak and pitch pine. Black cherry ( $P$. serotina) and serviceberry were important berry-producing species in this area, and also can be indicative of site types that were ideal for habitation. Black cherry is present in areas that are slightly richer, indicating more mesic soil conditions; however in this area black cherry is not usually present in hydric or water-logged soil conditions [59]. This type of area would be most likely near a stream or source of water, an important feature when considering camp or habitation placement. Serviceberry, on the other hand, can be found in drier areas with more sandy soils. In this area of upstate New York, serviceberry can be found in association with oak and pine species, further adding to indicator potential in the form of a species association composed of important utilized species.

Important understory indicator species are blueberry, raspberry (Rubus spp), lambs quarters, mayapple (Podophylum peltatum), and Indian cucumber root (Medeola virginiana). Blueberry was especially useful to Native Americans, throughout its range. There are many ethnohistoric accounts of the use of blueberries, throughout the year and in a great variety of dishes and variations $[60,61]$ (Table 1$)$.

Table 1: Fort Drum Army Installation, NY indicator species and uses.

\begin{tabular}{|c|c|}
\hline Species & Uses \\
\hline White oak (Quercus alba) & $\begin{array}{l}\text { acorns ground for flour, food } \\
\text { source in winter months }\end{array}$ \\
\hline Red oak (Quercus rubra) & $\begin{array}{l}\text { acorns soaked to remove tannins } \\
\text { and ground for flour }\end{array}$ \\
\hline White pine (Pinus strobus) & $\begin{array}{c}\text { materials source, indicate } \\
\text { significant disturbance regime }\end{array}$ \\
\hline Red pine (Pinus resinosa) & $\begin{array}{l}\text { indicate disturbance regime and } \\
\text { used for boat building }\end{array}$ \\
\hline Pitch pine (Pinus rigida) & $\begin{array}{l}\text { materials source, indicate } \\
\text { significant fire history }\end{array}$ \\
\hline Black cherry (Prunus serotina) & $\begin{array}{c}\text { utilized as a source of fruit in mid } \\
\text { to late summer }\end{array}$ \\
\hline Blueberry (Vaccinium spp) & $\begin{array}{l}\text { heavily utilized as a source of } \\
\text { fruit, patches tended }\end{array}$ \\
\hline Blackberry (Rubus spp) & utilized as a source of fruit \\
\hline $\begin{array}{c}\text { Wild strawberry (Fragaria } \\
\text { virginiana) }\end{array}$ & utilized as a source of fruit \\
\hline $\begin{array}{c}\text { Serviceberry (Amelanchier } \\
\text { arborea) }\end{array}$ & utilized as a source of fruit \\
\hline $\begin{array}{c}\text { Lambs quarters (Chenopodium } \\
\text { album) }\end{array}$ & $\begin{array}{l}\text { grain source, actively cultivated } \\
\text { and transplanted }\end{array}$ \\
\hline Mayapple (Podophylum peltatum) & $\begin{array}{l}\text { fruits eaten, root used to make a } \\
\text { topical ointment }\end{array}$ \\
\hline $\begin{array}{c}\text { Indian cucumber (Medeola } \\
\text { virginiana) }\end{array}$ & $\begin{array}{l}\text { root eaten raw or cooked, whole } \\
\text { plant harvested in fall }\end{array}$ \\
\hline
\end{tabular}

Indicator species identified at Quantico also included important mast-producing species such as oak and hickory (Table 2). However the location of this area along an important waterway such as the Potomac River facilitated a different culture than that of the Iroquois further north. Resources 


\section{Global Journal of Archaeology \& Anthropology}

obtained from the Potomac were abundant fish, freshwater mussels, and several aquatic herbaceous plants whose roots were important sources of fiber for the Native Americans, most notably tuckahoe (Peltandra virginica) [62]. Habitation sites were much of the time close to the waterway and its tributaries, where rich soils facilitated species such as white oak (Q. alba) and paw paw. However, in higher bluffs surrounding these areas, sandy soils create an ideal site for mixed-oak and hickory stands, with abundant blueberry and serviceberry in the understory. In these upland areas, white pine was also an important source of materials, and is indicative of significant disturbance regimes including repeated understory burning (Table 2) [58].

Table 2: Marine Corps Base Quantico, VA indicator species and uses.

\begin{tabular}{|c|c|}
\hline Species & Uses \\
\hline White oak (Quercus alba) & $\begin{array}{l}\text { acorns ground for flour, food } \\
\text { source in winter months }\end{array}$ \\
\hline $\begin{array}{l}\text { Northern \& southern red oak } \\
\text { (Quercus spp) }\end{array}$ & $\begin{array}{l}\text { acorns soaked to remove tannins } \\
\text { and ground for flour }\end{array}$ \\
\hline Hickory (Carya spp) & $\begin{array}{l}\text { several species utilized as } \\
\text { sources of mast }\end{array}$ \\
\hline White pine (Pinus strobus) & $\begin{array}{c}\text { materials source, indicate } \\
\text { significant disturbance regime }\end{array}$ \\
\hline Black cherry (Prunus serotina) & $\begin{array}{l}\text { utilized as a source of fruit in mid } \\
\text { to late summer }\end{array}$ \\
\hline Paw paw (Asimina triloba) & $\begin{array}{l}\text { utilized as a source of fruit, } \\
\text { possibly transplanted }\end{array}$ \\
\hline Blueberry (Vaccinium spp) & $\begin{array}{l}\text { heavily utilized as a source of } \\
\text { fruit, patches tended }\end{array}$ \\
\hline Blackberry (Rubus spp) & utilized as a source of fruit \\
\hline Serviceberry (Amelanchier spp.) & utilized as a source of fruit \\
\hline Spicebush (Lindera benzoin) & $\begin{array}{l}\text { utilized as a medicinal and to } \\
\text { brew tea }\end{array}$ \\
\hline Mayapple (Podophylum peltatum) & $\begin{array}{l}\text { fruits eaten, root used to make a } \\
\text { topical ointment }\end{array}$ \\
\hline Tuckahoe (Peltandra virginica) & $\begin{array}{l}\text { plant harvested and all parts } \\
\text { boiled/dried and eaten }\end{array}$ \\
\hline
\end{tabular}

At the Cheatham Annex, several important mast-producers were present in the presettlement forest overstory, and in high abundance (Table 3). These included white oak, southern red oak (Q. falcata), chinquapin (C. pumila), beech (Fagus grandifolia), and hickory. However here, several fruit-producing species were also prevalent, as well as freshwater resources such as tuckahoe, and higher populations of mussels in the more brackish water of the Tidewater area. The Cheatham Annex itself and the Wilderness Area in particular are situated on relatively high bluffs along waterways such as Queen Creek, where sandy soils allow species such as oak, pine, blueberry, and serviceberry to proliferate (Table 3).
Table 3: Cheatham Annex Naval Supply Station, VA indicator species and uses.

\begin{tabular}{|c|c|}
\hline Species & Uses \\
\hline White oak (Quercus alba) & $\begin{array}{l}\text { acorns ground for flour, food } \\
\text { source in winter months }\end{array}$ \\
\hline $\begin{array}{l}\text { Southern red oak (Quercus } \\
\text { falcata) }\end{array}$ & $\begin{array}{l}\text { acorns ground for flour, food } \\
\text { source in winter months }\end{array}$ \\
\hline Chinquapin (Castanea pumila) & utilized as a source of mast \\
\hline Beech (Fagus americana) & utilized as a source of mast \\
\hline Hickory (Carya spp) & utilized as sources of mast \\
\hline Loblolly pine (Pinus taeda) & $\begin{array}{c}\text { materials source, bark edible in } \\
\text { emergencies }\end{array}$ \\
\hline Blueberry (Vaccinium spp) & $\begin{array}{l}\text { utilized as a source of fruit, } \\
\text { patches tended to ensure supply }\end{array}$ \\
\hline Paw paw (Asimina triloba) & $\begin{array}{l}\text { utilized as a source of fruit, } \\
\text { possibly transplanted }\end{array}$ \\
\hline $\begin{array}{c}\text { Persimmon (Diospyros } \\
\text { virginiana) }\end{array}$ & utilized as a source of fruit \\
\hline Spicebush (Lindera benzoin) & $\begin{array}{l}\text { utilized as a medicinal and to } \\
\text { brew tea }\end{array}$ \\
\hline Serviceberry (Amelanchier spp) & utilized as a source of fruit \\
\hline Blackberry (Rubus spp) & utilized as a source of fruit \\
\hline Tuckahoe (Peltandra virginica) & $\begin{array}{l}\text { plant harvested and all parts } \\
\text { boiled/dried and eaten }\end{array}$ \\
\hline
\end{tabular}

At Fort Drum in upstate New York, overstory tree species composition is typical of the northern hardwood forest type, including high prevalence of American beech, birch (Betula spp), sugar maple (Acer saccharum) and other maples, eastern hemlock (Tsuga canadensis), and rich-site species such as tulip poplar (Liriodendron tulipifera) (Table 4). In this northern hardwood forest matrix, inclusions of oak, pine, and other disturbance-adapted and drier-site species can be indicative of land use history causing setbacks to the successional process that perpetuate mid-successional disturbance adapted tree species. Native American land uses, especially the use of fire in an area where lightening ignitions were infrequent, were prevalent enough to cause these changes in forest composition [8,31].

At Fort Drum, NY, significant differences in importance values exist between several species on archaeological sites and off-site areas, including red maple (A. rubrum), red pine, paper birch (B. papyrifera), scarlet oak (Q. coccinea), quaking aspen (Populus tremuloides), and basswood (Tilia americana) which were more prevalent on off-site areas than archaeological sites ( $\mathrm{p}<0.05$; Table 4). White ash (Fraxinus americana), black (A. nigrum) and silver maple (A. saccharinum), and common buckthorn (Rhamnus cathartica) were all significantly more prevalent on archaeological sites than off-site areas $(\mathrm{p}<0.05)$. When significant differences at $\mathrm{p}$ values less than 0.1 were considered, white oak and white pine are significantly more prevalent on archaeological sites than off-site areas. Many significant differences at $\mathrm{p}$ values less than 0.05 were present because the species was only discovered on one site, or one type of site, and most of these differences are occurring between 
species that are not considered cultural indicators, or important in the ethnobotanical record. It is important to note the higher prevalence of white oak and white pine on archaeological sites, versus the higher prevalence of species such as red maple and paper birch on off-site areas. Another important result from this analysis are much lower tree densities (stems/ha, Table 4) occurring on archaeological sites (2024) versus off-site areas (2471). This indicates that continued use of these areas by Native Americans (and possibly subsequently by early European settlers) may have kept them more open to the present day.

Table 4: Compiled overstory data for archaeological sites ("Arch.") and off-site areas ("Off-Site") at Fort Drum, NY. First columns under each heading indicate raw data, second columns indicate relative data. Significant differences between importance values on archaeological sites versus off-site areas at an alpha level of $0.05(p<0.05)$ are indicated by $\left({ }^{* *}\right)$ next to the species name, while significant differences at an alpha level of $0.1(p<0.1)$ are indicated by $a\left(^{*}\right)$.

\begin{tabular}{|c|c|c|c|c|c|c|c|c|c|c|c|c|c|c|c|c|}
\hline \multirow{3}{*}{$\begin{array}{c}\text { Species } \\
\text { Sugar maple }\end{array}$} & \multicolumn{4}{|c|}{$\begin{array}{c}\text { Density (stems/ha) \& Rel. } \\
\text { Density }\end{array}$} & \multicolumn{4}{|c|}{$\begin{array}{c}\text { Dominance }\left(\mathrm{m}^{2} / \mathrm{ha}\right) \& \text { Rel. } \\
\text { Dominance }\end{array}$} & \multicolumn{4}{|c|}{$\begin{array}{c}\text { Frequency (\# of plots) \& } \\
\text { Rel. Frequency }\end{array}$} & \multicolumn{4}{|c|}{ Importance Value \& RIV } \\
\hline & \multicolumn{2}{|c|}{ Arch. } & \multicolumn{2}{|c|}{ Off-Site } & \multicolumn{2}{|c|}{ Arch. } & \multicolumn{2}{|c|}{ Off-Site } & \multicolumn{2}{|c|}{ Arch. } & \multicolumn{2}{|c|}{ Off-Site } & \multicolumn{2}{|c|}{ Arch. } & \multicolumn{2}{|c|}{ Off-Site } \\
\hline & 401.8 & 19.9 & 464.8 & 18.8 & 26.6 & 23.8 & 22.8 & 22.4 & 17 & 17 & 11 & 14.5 & 60.6 & 20.2 & 55.7 & 18.6 \\
\hline Northern red oak & 371.4 & 18.4 & 464.8 & 18.8 & 20.7 & 18.5 & 21.6 & 21.3 & 15 & 15 & 11 & 14.5 & 51.9 & 17.3 & 54.6 & 18.2 \\
\hline White oak* & 288 & 14.2 & 269.1 & 10.9 & 12.1 & 10.8 & 6.8 & 6.7 & 15 & 15 & 7 & 9.2 & 40 & 13.3 & 26.8 & 8.9 \\
\hline Black cherry & 197.1 & 9.7 & 146.8 & 5.9 & 10.9 & 9.8 & 8.4 & 8.3 & 7 & 7 & 5 & 6.6 & 26.5 & 8.8 & 20.8 & 6.9 \\
\hline White pine* & 181.9 & 9 & 146.8 & 5.9 & 17.9 & 16 & 4.1 & 4 & 12 & 12 & 7 & 9.2 & 37 & 12.3 & 19.2 & 6.4 \\
\hline Eastern hemlock & 121.3 & 6 & 134.5 & 5.4 & 6.1 & 5.5 & 6.4 & 6.3 & 4 & 4 & 3 & 3.9 & 15.5 & 5.2 & 15.7 & 5.2 \\
\hline Red maple** & 106.1 & 5.2 & 354.7 & 14.4 & 4.8 & 4.3 & 8 & 7.9 & 6 & 6 & 9 & 11.8 & 15.5 & 5.2 & 34.1 & 11.4 \\
\hline $\begin{array}{c}\text { Eastern } \\
\text { hophornbeam }\end{array}$ & 75.8 & 3.7 & 85.6 & 3.5 & 0.7 & 0.6 & 1.2 & 1.1 & 4 & 4 & 4 & 5.3 & 8.4 & 2.8 & 9.9 & 3.3 \\
\hline American beech & 53.1 & 2.6 & 24.5 & 1 & 1.2 & 1.1 & 1.4 & 1.4 & 3 & 3 & 2 & 2.6 & 6.7 & 2.2 & 5 & 1.7 \\
\hline Mockernut hickory & 45.5 & 2.2 & 48.9 & 2 & 1.8 & 1.6 & 3.3 & 3.3 & 3 & 3 & 2 & 2.6 & 6.9 & 2.3 & 7.9 & 2.6 \\
\hline White ash** & 37.9 & 1.9 & - & - & 1.7 & 1.6 & - & - & 4 & 4 & - & - & 7.4 & 2.5 & - & - \\
\hline Red pine ${ }^{* *}$ & 30.3 & 1.5 & 122.3 & 5 & 1.6 & 1.4 & 8 & 7.9 & 2 & 2 & 5 & 6.6 & 4.9 & 1.6 & 19.4 & 6.5 \\
\hline Black maple** & 30.3 & 1.5 & - & - & 1.9 & 1.7 & - & - & 2 & 2 & - & - & 5.2 & 1.7 & - & - \\
\hline Silver maple ${ }^{* *}$ & 30.3 & 1.5 & - & - & 2.7 & 2.4 & - & - & 1 & 1 & - & - & 4.9 & 1.6 & - & - \\
\hline Serviceberry & 22.7 & 1.1 & 48.9 & 2 & 0.2 & 0.2 & 0.3 & 0.3 & 1 & 1 & 3 & 3.9 & 2.3 & 0.8 & 6.2 & 2.1 \\
\hline Green ash & 7.6 & 0.4 & - & - & 0.1 & 0.1 & - & - & 1 & 1 & - & - & 1.5 & 0.5 & - & - \\
\hline Paper birch** & 7.6 & 0.4 & 36.7 & 1.5 & 0.6 & 0.6 & 2.9 & 2.9 & 1 & 1 & 2 & 2.6 & 1.9 & 0.6 & 7 & 2.3 \\
\hline Black walnut & 7.6 & 0.4 & 12.2 & 0.5 & 0.1 & 0.1 & 0.1 & 0.1 & 1 & 1 & 1 & 1.3 & 1.4 & 0.5 & 1.9 & 0.6 \\
\hline $\begin{array}{l}\text { Common } \\
\text { buckthorn }\end{array}$ & 7.6 & 0.4 & - & - & 0.1 & 0 & - & - & 1 & 1 & - & - & 1.4 & 0.5 & - & - \\
\hline Scarlet oak** & - & - & 61.2 & 2.5 & - & - & 4.3 & 4.2 & - & - & 2 & 2.6 & - & - & 9.3 & 3.1 \\
\hline Quaking aspen** & - & - & 24.5 & 1 & - & - & 1.7 & 1.7 & - & - & 1 & 1.3 & - & - & 4 & 1.3 \\
\hline Basswood** & - & - & 24.5 & 1 & - & - & 0.4 & 0.3 & - & - & 1 & 1.3 & - & - & 2.7 & 0.9 \\
\hline TOTAL & 2024 & 100 & 2471 & 100 & 112 & 100 & 102 & 100 & 100 & 100 & 76 & 100 & 300 & 100 & 300 & 100 \\
\hline
\end{tabular}

At Marine Corps Base Quantico in Virginia, the dominant forest type is mixed hardwood, with high prevalence of oak-pine forests on sandy bluffs, and the addition of American beech, sweetgum (Liquidambar styraciflua), and tulip poplar in mesic areas and along waterways (Table 5). White oak, chestnut oak ( $Q$. montana), blackjack oak (Q. marilandica), and bitternut hickory (C. cordiformis) had significantly higher importance values on archaeological sites than off-site areas (alpha level of 0.05 ). Black walnut and flowering dogwood (Cornus florida) were significantly more prevalent on archaeological sites at an alpha level of 0.1. Slippery elm (Ulmus rubra) was more prevalent on off-site areas (alpha level=0.05), and tulip poplar was just over the significance level ( $\mathrm{p}$-value=0.066) with higher importance on off-site areas. The most notable differences between archaeological sites and off-site areas are in the amount of white oak on archaeological sites, and the amount of tulip poplar and red maple on off-site areas (although red maple presence is more variable among sites, precluding a statistically significant 
comparison).

Most of the species that were more prevalently found on archaeological sites are important sources of food for Late Woodland and Mississippian Time Period Native Americans of this area (more important during the Late Woodland when hunting and gathering activities were the main source of sustenance), and were also perpetuated through disturbances such as fire and clearing $[3,12,25,26]$. These species include oaks, hickories, and walnut. This is very notable, and indicates that these species are excellent candidates for indicator vegetation to allow Cultural Resources Managers to more effectively locate archaeological sites in this area. This represents correlation, not causation, but is a very strong trend. Again here as at Fort Drum, archaeological sites show decreased tree densities (1682 stems/ ha, Table 5) when compared with associated off-site areas (1857 stems/ha), leading to the conclusion that archaeological sites may have remained more open throughout the time since European Contact.

Table 5: Compiled overstory data for archaeological sites ("Arch.") and off-site areas ("Off-Site") at MCB Quantico, VA. First columns under each heading indicate raw data, second columns indicate relative data. Significant differences between importance values on archaeological sites versus off-site areas at an alpha level of $0.05(p<0.05)$ are indicated by $\left.{ }^{* *}\right)$ next to the species name, while significant differences at an alpha level of $0.1(p<0.1)$ are indicated by $a\left({ }^{*}\right)$.

\begin{tabular}{|c|c|c|c|c|c|c|c|c|c|c|c|c|c|c|c|c|}
\hline \multirow{3}{*}{$\begin{array}{c}\text { Species } \\
\text { White oak** }\end{array}$} & \multicolumn{4}{|c|}{$\begin{array}{c}\text { Density (stems/ha) \& Rel. } \\
\text { Density }\end{array}$} & \multicolumn{4}{|c|}{$\begin{array}{c}\text { Dominance }\left(\mathrm{m}^{2} / \mathrm{ha}\right) \& \text { Rel. } \\
\text { Dominance }\end{array}$} & \multicolumn{4}{|c|}{$\begin{array}{l}\text { Frequency (\# of plots) } \\
\text { \& Rel. Frequency }\end{array}$} & \multicolumn{4}{|c|}{ Importance Value \& RIV } \\
\hline & \multicolumn{2}{|c|}{ Arch. } & \multicolumn{2}{|c|}{ Off-Site } & \multicolumn{2}{|c|}{ Arch. } & \multicolumn{2}{|c|}{ Off-Site } & \multicolumn{2}{|c|}{ Arch. } & \multicolumn{2}{|c|}{ Off-Site } & \multicolumn{2}{|c|}{ Arch. } & \multicolumn{2}{|c|}{ Off-Site } \\
\hline & 451.7 & 26.9 & 174.9 & 9.4 & 81.1 & 42.5 & 18.6 & 10.6 & 24 & 21.2 & 8 & 10.3 & 90.6 & 30.2 & 30.2 & 10.1 \\
\hline Sweetgum & 163.4 & 9.7 & 201.8 & 10.9 & 15.4 & 8.1 & 26.2 & 14.8 & 12 & 10.6 & 8 & 10.3 & 28.4 & 9.5 & 36 & 12 \\
\hline American beech & 144.2 & 8.6 & 215.3 & 11.6 & 3.4 & 1.8 & 11.4 & 6.5 & 9 & 8 & 6 & 7.7 & 18.3 & 6.1 & 25.8 & 8.6 \\
\hline $\begin{array}{c}\text { American } \\
\text { hornbeam }\end{array}$ & 144.2 & 8.6 & 40.4 & 2.2 & 1 & 0.5 & 1 & 0.6 & 7 & 6.2 & 3 & 3.8 & 15.3 & 5.1 & 6.6 & 2.2 \\
\hline Mockernut hickory & 124.9 & 7.4 & 134.5 & 7.2 & 8.3 & 4.3 & 7.5 & 4.3 & 10 & 8.8 & 4 & 5.1 & 20.6 & 6.9 & 16.6 & 5.5 \\
\hline Chestnut oak** & 105.7 & 6.3 & 13.5 & 0.7 & 14.3 & 7.5 & 0.3 & 0.2 & 3 & 2.7 & 1 & 1.3 & 16.5 & 5.5 & 2.2 & 0.7 \\
\hline Northern red oak & 105.7 & 6.3 & 134.5 & 7.2 & 31.4 & 16.5 & 13.6 & 7.7 & 10 & 8.8 & 8 & 10.3 & 31.6 & 10.5 & 25.2 & 8.4 \\
\hline Tulip poplar* & 76.9 & 4.6 & 349.8 & 18.8 & 16.7 & 8.7 & 71.3 & 40.4 & 5 & 4.4 & 13 & 16.7 & 17.7 & 5.9 & 75.9 & 25.3 \\
\hline Red maple & 76.9 & 4.6 & 349.8 & 18.8 & 1.1 & 0.6 & 7.7 & 4.4 & 8 & 7.1 & 12 & 15.4 & 12.2 & 4.1 & 38.6 & 12.9 \\
\hline Blackgum & 48.1 & 2.9 & 121.1 & 6.5 & 0.8 & 0.4 & 2.7 & 1.6 & 5 & 4.4 & 6 & 7.7 & 7.7 & 2.6 & 15.8 & 5.3 \\
\hline Virginia pine & 48.1 & 2.9 & 26.9 & 1.4 & 3.2 & 1.7 & 3.3 & 1.9 & 2 & 1.8 & 2 & 2.6 & 6.3 & 2.1 & 5.9 & 2 \\
\hline Black oak & 38.4 & 2.3 & 26.9 & 1.4 & 6.4 & 3.4 & 6.7 & 3.8 & 4 & 3.5 & 2 & 2.6 & 9.2 & 3.1 & 7.8 & 2.6 \\
\hline $\begin{array}{l}\text { Flowering } \\
\text { dogwood* }^{*}\end{array}$ & 38.4 & 2.3 & - & - & 0.4 & 0.2 & - & - & 3 & 2.7 & - & - & 5.1 & 1.7 & - & - \\
\hline American holly & 28.8 & 1.7 & 13.5 & 0.7 & 0.5 & 0.2 & 0.1 & 0.1 & 3 & 2.7 & 1 & 1.3 & 4.6 & 1.5 & 2.1 & 0.7 \\
\hline Pignut hickory & 28.8 & 1.7 & 13.5 & 0.7 & 1.9 & 1 & 0.1 & 0.1 & 3 & 2.7 & 1 & 1.3 & 5.4 & 1.8 & 2.1 & 0.7 \\
\hline Blackjack oak** & 19.2 & 1.1 & - & - & 1.8 & 0.9 & - & - & 1 & 0.9 & - & - & 3 & 1 & - & - \\
\hline Black walnut* & 9.6 & 0.6 & - & - & 0.2 & 0.1 & - & - & 1 & 0.9 & - & - & 1.6 & 0.5 & - & - \\
\hline Southern red oak & 9.6 & 0.6 & 13.5 & 0.7 & 0.9 & 0.5 & 5 & 2.9 & 1 & 0.9 & 1 & 1.3 & 1.9 & 0.6 & 4.9 & 1.6 \\
\hline Bitternut hickory** & 9.6 & 0.6 & - & - & 1.9 & 1 & - & - & 1 & 0.9 & - & - & 2.5 & 0.8 & - & - \\
\hline Ash species* & 9.6 & 0.6 & - & - & 0.3 & 0.2 & - & - & 1 & 0.9 & - & - & 1.6 & 0.5 & - & - \\
\hline Slippery elm** & - & - & 13.5 & 0.7 & - & - & 0.6 & 0.3 & - & - & 1 & 1.3 & - & - & 2.3 & 0.8 \\
\hline Eastern redcedar & - & - & 13.5 & 0.7 & - & - & 0.1 & 0 & - & - & 1 & 1.3 & - & - & 2 & 0.7 \\
\hline TOTAL & 1682 & 100 & 1857 & 100 & 191 & 100 & 176 & 100 & 113 & 100 & 78 & 100 & 300 & 100 & 300 & 100 \\
\hline
\end{tabular}

Forest overstory composition in York County, Virginia, the location of the Cheatham Annex Naval Supply Station, is similar to that of MCB Quantico. The mixed hardwood forest type dominates, with shifts in prevalence of certain species depending on soil moisture conditions. Tulip poplar and sweetgum, and cherry to a certain extent, dominated in more mesic conditions, while oak, hickory, and loblolly pine (P. taeda) dominated in the majority of the Wilderness Area along sandy bluffs above Queen 
Creek. The majority of archaeological sites were located in the Wilderness Area, and contained a higher importance of xericadapted species that were important in the Native American diet.

At the Cheatham Annex, VA, tulip poplar, northern red oak $(Q$. rubra), and loblolly pine were well represented in cultural sites discovered both through traditional methods and shell midden evidence (Table 6). Significant differences exist in importance of sweetgum, eastern red cedar (Juniperus virginiana), and black walnut (alpha level of 0.05; Table 6). White oak and hickory species were exclusively found on sites discovered with shell midden evidence (oaks significantly different at alpha level of 0.05 , hickory at alpha level of 0.1 ). This suggests that the southern shore of Queen Creek was an important area for Late Woodland Native American activity, and the primary driving force in Native American habitation was likely the presence of food resources in the Creek itself, as well as high prevalence of utilized plants throughout the area. In addition, food and resource gathering activities occurred further inland in the areas where the oak and hickory species thrived on the drier, sandier soils of the river bluffs. The rather ubiquitous use by Native Americans of both riparian and upland sites in this area makes it difficult to elucidate differences in vegetation composition between cultural and non-cultural sites. The various ways in which this landscape was used may have perpetuated cultural indicator species throughout the area, and indeed many important mast and fruit producing species are located close along the shore of Queen Creek, including white oak, Allegheny chinquapin, and persimmon (Diospyros virginiana). This area does not show shell midden evidence, however it was most likely heavily traversed. Overstory tree densities are much higher on sites discovered with shell midden evidence (1521 stems/ha) than on sites discovered through traditional testing (1101 stems/ha, Table 6). I believe this is because traditional testing took place in an area planned for a boat launch, which was more low-lying and periodically flooded, and thus had more understory vegetation and less overstory trees than shell midden sites. The differences seen between these two types of archaeological sites provides further evidence for ubiquitous use of the area, regardless of vegetation characteristics.

Table 6: Compiled overstory data for archaeological sites ("Arch.") and sites identified through shell midden evidence ("Midden") at Cheatham Annex Naval Supply Station, VA. First columns under each heading indicate raw data, second columns indicate relative data. Significant differences between importance values on archaeological sites discovered through traditional testing versus those discovered with shell midden evidence at an alpha level of $0.05(p<0.05)$ are indicated by $\left({ }^{* *}\right)$ next to the species name, while significant differences at an alpha level of 0.1 $(p<0.1)$ are indicated by $a\left(^{*}\right)$.

\begin{tabular}{|c|c|c|c|c|c|c|c|c|c|c|c|c|c|c|c|c|}
\hline \multirow{3}{*}{$\begin{array}{c}\text { Species } \\
\text { Sweetgum** }\end{array}$} & \multicolumn{4}{|c|}{$\begin{array}{c}\text { Density (stems/ha) \& Rel. } \\
\text { Density }\end{array}$} & \multicolumn{4}{|c|}{$\begin{array}{c}\text { Dominance }\left(\mathrm{m}^{2} / \mathrm{ha}\right) \& \text { Rel. } \\
\text { Dominance }\end{array}$} & \multicolumn{4}{|c|}{$\begin{array}{c}\text { Frequency (\# of plots) \& } \\
\text { Rel. Frequency }\end{array}$} & \multicolumn{4}{|c|}{ Importance Value \& RIV } \\
\hline & \multicolumn{2}{|c|}{ Arch. } & \multicolumn{2}{|c|}{ Midden } & \multicolumn{2}{|c|}{ Arch. } & \multicolumn{2}{|c|}{ Midden } & \multicolumn{2}{|c|}{ Arch. } & \multicolumn{2}{|c|}{ Midden } & \multicolumn{2}{|c|}{ Arch. } & \multicolumn{2}{|c|}{ Midden } \\
\hline & 269.1 & 24.4 & - & - & 13 & 15.9 & - & - & 7 & 20.6 & - & - & 60.9 & 20.3 & - & - \\
\hline Eastern redcedar** & 171.2 & 15.6 & 46.8 & 3.1 & 7.6 & 9.2 & 0.6 & 0.5 & 6 & 17.6 & 2 & 4.1 & 42.4 & 14.1 & 7.6 & 2.5 \\
\hline Tulip poplar & 146.8 & 13.3 & 140.4 & 9.2 & 29.5 & 36 & 23.8 & 17.1 & 5 & 14.7 & 4 & 8.2 & 64 & 21.3 & 34.5 & 11.5 \\
\hline Northern red oak & 146.8 & 13.3 & 140.4 & 9.2 & 15.1 & 18.5 & 13.1 & 9.4 & 3 & 8.8 & 5 & 10.2 & 40.6 & 13.5 & 28.8 & 9.6 \\
\hline Flowering dogwood & 73.4 & 6.7 & 117 & 7.7 & 1 & 1.2 & 0.9 & 0.6 & 3 & 8.8 & 3 & 6.1 & 16.7 & 5.6 & 14.5 & 4.8 \\
\hline Black walnut** & 73.4 & 6.7 & - & - & 10.6 & 12.9 & - & - & 3 & 8.8 & - & - & 28.4 & 9.5 & - & - \\
\hline Loblolly pine & 73.4 & 6.7 & 70.2 & 4.6 & 2 & 2.5 & 10.8 & 7.8 & 2 & 5.9 & 2 & 4.1 & 15 & 5 & 16.5 & 5.5 \\
\hline Black cherry* & 48.9 & 4.4 & - & - & 0.4 & 0.5 & - & - & 1 & 2.9 & - & - & 7.9 & 2.6 & - & - \\
\hline $\begin{array}{c}\text { Common } \\
\text { hackberry** }\end{array}$ & 24.5 & 2.2 & - & - & 1.8 & 2.2 & - & - & 1 & 2.9 & - & - & 7.3 & 2.4 & - & - \\
\hline Black locust & 24.5 & 2.2 & - & - & 0.1 & 0.2 & - & - & 1 & 2.9 & - & - & 5.3 & 1.8 & - & - \\
\hline American beech ${ }^{* *}$ & 24.5 & 2.2 & 117 & 7.7 & 0.6 & 0.7 & 13.8 & 9.9 & 1 & 2.9 & 3 & 6.1 & 5.9 & 2 & 23.7 & 7.9 \\
\hline Sassafras* & 24.5 & 2.2 & - & - & 0.2 & 0.2 & - & - & 1 & 2.9 & - & - & 5.4 & 1.8 & - & - \\
\hline Swamp white oak** & - & - & 163.8 & 10.8 & - & - & 16.7 & 12 & - & - & 6 & 12.2 & - & - & 35 & 11.7 \\
\hline Pignut hickory* & - & - & 70.2 & 4.6 & - & - & 0.6 & 0.5 & - & - & 2 & 4.1 & - & - & 9.2 & 3.1 \\
\hline American holly* & - & - & 234 & 15.4 & - & - & 2.2 & 1.6 & - & - & 6 & 12.2 & - & - & 29.2 & 9.7 \\
\hline Red maple** & - & - & 163.8 & 10.8 & - & - & 15.5 & 11.1 & - & - & 6 & 12.2 & - & - & 34.1 & 11.4 \\
\hline Mockernut hickory & - & - & 23.4 & 1.5 & - & - & 0.1 & 0.1 & - & - & 1 & 2 & - & - & 3.7 & 1.2 \\
\hline White oak ${ }^{* *}$ & - & - & 234 & 15.4 & - & - & 40.8 & 29.4 & - & - & 9 & 18.4 & - & - & 63.1 & 21 \\
\hline TOTAL & 1101 & 100 & 1521 & 100 & & 100 & 139 & 100 & 34 & 100 & 49 & 100 & 300 & 100 & 300 & 100 \\
\hline
\end{tabular}


Table 7: Soil charcoal results for archaeological and off-site areas on Fort Drum, NY. Samples were considered positive for soil charcoal if they contained coarse soil charcoal ( $>1 \mathrm{~mm}$ in diameter), and sites were considered positive if at least $50 \%$ of samples contained coarse soil charcoal. A ' - " indicates that no suitable off-site area was located for comparison with the cultural site, due to military activities and/or construction.

\begin{tabular}{|c|c|c|}
\hline Site & Arch. & Control \\
\hline Turtle Cairn Site & 50 & 33 \\
\hline Boat Building Site & 66 & 100 \\
\hline Camp Drum 1 & 33 & 0 \\
\hline Calendar Site & 71 & - \\
\hline FDP1021 & 0 & - \\
\hline FDP1090 & 100 & - \\
\hline FDP1242 & 100 & - \\
\hline FDP1244 & 100 & - \\
\hline FDP1161 & 60 & 75 \\
\hline FDP1267 & 100 & 100 \\
\hline FDP1268 & 50 & 0 \\
\hline FDP1266 & 0 & 0 \\
\hline FDP1210 & 0 & - \\
\hline FDP1272 & 100 & 100 \\
\hline ASOS Site & 50 & 33 \\
\hline
\end{tabular}

Across all study sites, the presence of soil charcoal on and off cultural sites was somewhat variable (Tables 7-9). At Fort Drum, charcoal was present in a greater number of samples from cultural sites than from off-site areas (Table 7), however when soil samples from an archaeological site were positive for soil charcoal, samples from the off-site area tended to be positive as well. Most archaeological sites surveyed at Fort Drum had at least $50 \%$ of samples positive for soil charcoal (11 out of 15 cultural; Table 7). However, six of nine off-site areas on Fort Drum had at least 33\% of samples positive for coarse soil charcoal. At MCB Quantico, six of nine archaeological sites had $50 \%$ or greater positive samples compared with at least $20 \%$ for the associated off-site area (Table 8). The presence of coarse soil charcoal in many off-site areas, albeit reduced relative to cultural sites, may suggest that Native American burning "spilled over" into the adjacent off-site areas used in this study. This analysis has potential to aid in delineation of a "sphere of influence" of any Native American village or significant habitation site.
Table 8: Soil charcoal results for archaeological and off-site areas on MCB Quantico, VA. Samples were considered positive for soil charcoal if they contained coarse soil charcoal ( $>1 \mathrm{~mm}$ in diameter), and sites were considered positive if at least $50 \%$ of samples contained coarse soil charcoal. A ' - ' indicates that no suitable off-site area was located for comparison with the cultural site, due to military activities and/or construction.

\begin{tabular}{|c|c|c|}
\hline Site & Arch. & Control \\
\hline $1-1$ & 100 & 20 \\
\hline $1-2$ & 33 & 20 \\
\hline $1-3 a$ & 100 & 20 \\
\hline $1-3 b$ & 100 & 33 \\
\hline $1-4$ & 66 & 20 \\
\hline $1-5 / 1-6$ & 50 & 0 \\
\hline $2-2$ & 50 & 0 \\
\hline $4-2$ & 0 & 0 \\
\hline $6 \mathrm{~B}$ & 0 & 0 \\
\hline
\end{tabular}

Table 9: Soil charcoal results for archaeological sites discovered through traditional testing and through identification of shell midden evidence on Cheatham Annex, VA. Samples were considered positive for soil charcoal if they contained coarse soil charcoal $>1 \mathrm{~mm}$ in diameter), and sites were considered positive if at least $50 \%$ of samples contained coarse soil charcoal. A ' - ' indicates that no suitable off-site area was located for comparison with the cultural site, due to military activities and/or construction.

\begin{tabular}{|c|c|c|c|}
\hline & Site & Arch. & Control \\
\hline \multirow{5}{*}{ Traditional } & Boat Launch & 0 & - \\
\hline & Cellar & 33 & - \\
\hline & Site \#3 & 0 & - \\
\hline & B-8 & 0 & - \\
\hline & $\mathrm{C}-5$ & 0 & - \\
\hline \multirow{7}{*}{ Shell Midden } & 1 & 67 & - \\
\hline & 2 & 100 & - \\
\hline & 3 & 100 & - \\
\hline & 4 & 0 & - \\
\hline & 5 & 100 & - \\
\hline & 6 & 100 & - \\
\hline & 7 & 50 & - \\
\hline
\end{tabular}


Soil charcoal results at the Cheatham Annex, Virginia, were considered differently than those from Fort Drum and Quantico (Table 9). At Cheatham Annex 10 of the 12 study sites were located within the Wilderness Area, and all excavations tested positive for Late Woodland/Mississippian cultural activity. Therefore, all locations were either archaeological sites or midden sites. Over half of the sites sampled (7 of 12 cultural sites; Table 9) were positive for soil charcoal evidence, and all of these occurred within the Wilderness Area. These sites were dominated by oaks, hickories, and loblolly pine, all fire-tolerant and disturbance-adapted species. This indicates that although archaeological evidence is present throughout, the presence of soil charcoal is high correlated with the presence of many important indicator species. In conjunction, vegetation and soil charcoal data may increase the ability of Cultural Resources Management personnel to discern differing land use patterns in areas of ubiquitous Native American activity.

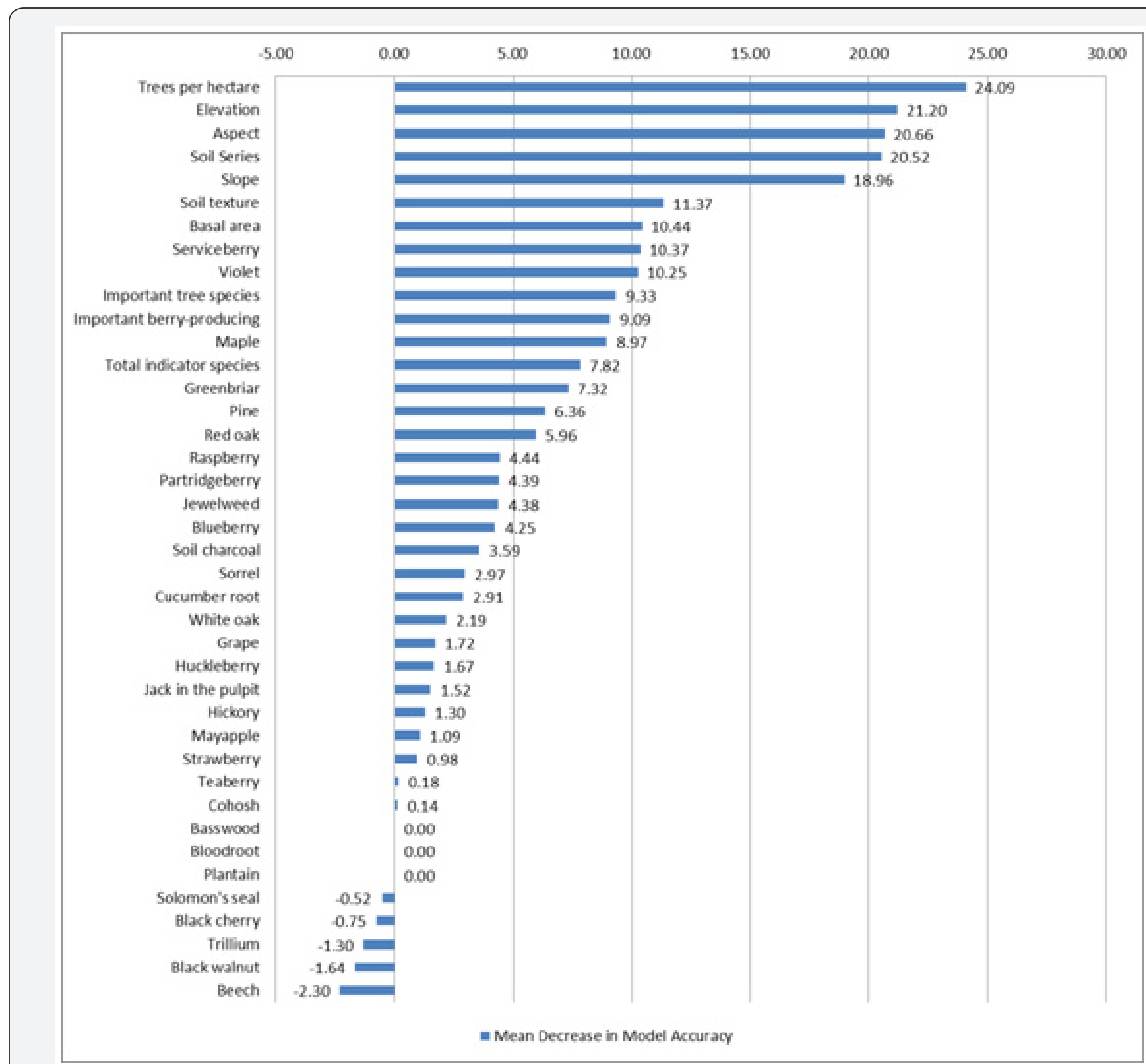

Figure 1: Importance values, or mean decrease in accuracy of the model, for predictor variables in a classification tree model predicting Treatment (archaeological or off-site area) for data collected at Fort Drum. 


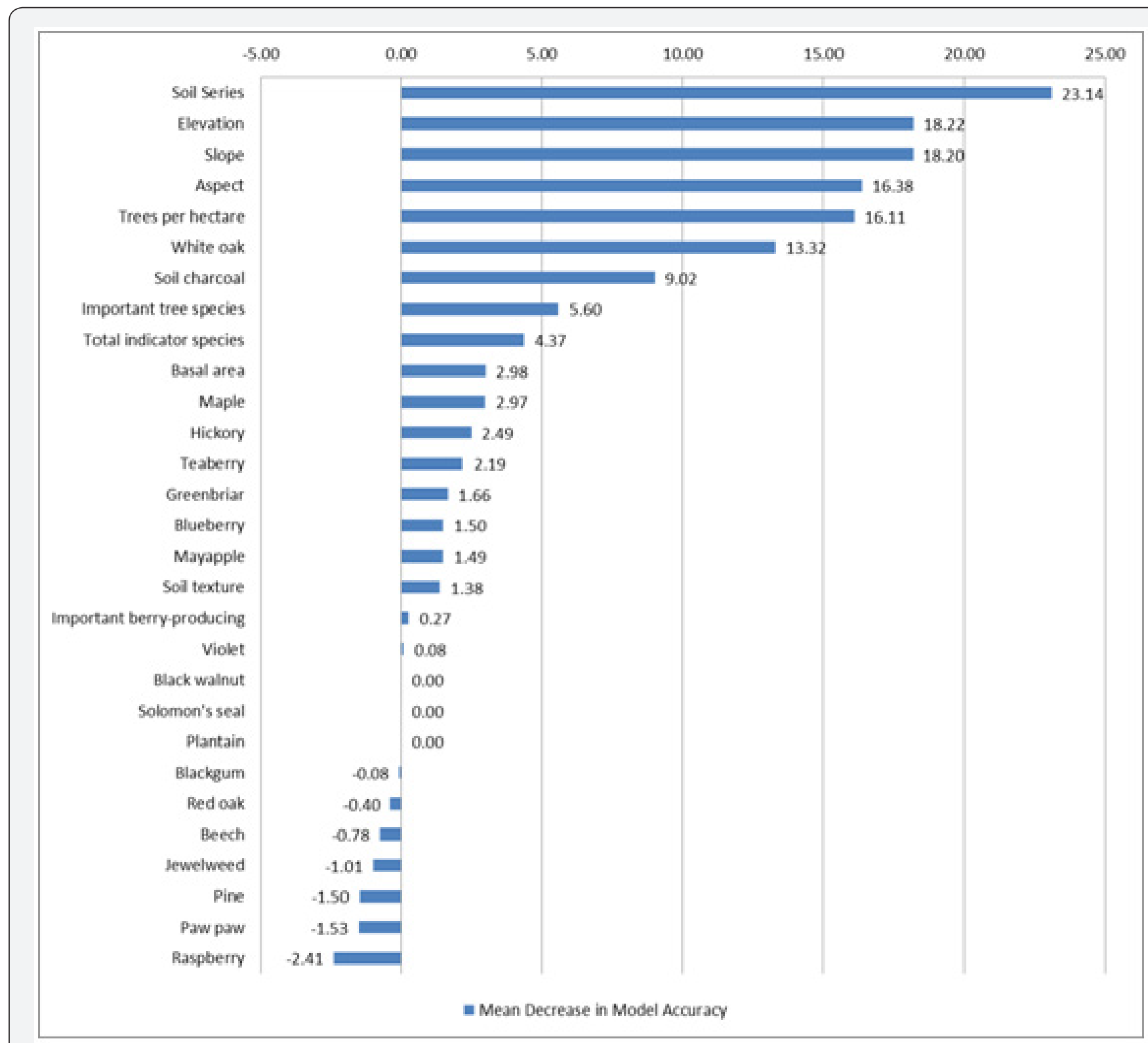

Figure 2: Importance values, or mean decrease in accuracy of the model, for predictor variables in a classification tree model predicting Treatment (archaeological or off-site area) for data collected at MCB Quantico.

Classification tree models were run for the two study sites where archaeological versus off-site areas could be identified, Fort Drum, New York, and MCB Quantico, Virginia (Figures 1 \& 2). The response variable for the classification models was treatment type (archaeological or off-site). Classification tree model results are reported here as importance values of predictor variables. Importance values are expressed as the percent increase in mean square error (MSE) of the model when the predictor variable in question is eliminated from the model (mean decrease in accuracy of the model). An importance value of $10 \%$ would therefore indicate that MSE of a model built without the predictor variable in question would have an MSE value 10\% higher than MSE of a model built including that predictor variable. Variables can be considered informative if their importance value is greater than the absolute value of the lowest negative-scoring predictor variable, because the importance values of irrelevant variables vary randomly around zero $[63,64]$. Classification tree model results from Fort Drum reveal that trees per hectare in each plot was the most significant of the predictors at an importance value of $24.1 \%$ (Figure 1 ). This supports the observation in the analysis of overstory composition of archaeological sites versus off-site areas that archaeological sites tend to be more open. Elevation, aspect, soil series, and slope follow closely behind with importance values ranging from $21.2 \%$ to $19.0 \%$. Presence/absence of all vegetation species range in importance from $10.4 \%$ (serviceberry) to $-2.3 \%$ (beech; negative importance values represent a decrease in model error when the variable is removed as a predictor, indicating 


\section{Global Journal of Archaeology \& Anthropology}

an increase in accuracy of the model and no relationship with the response variable). Important tree and berry-producing species both had importance values of about $9 \%$, total number of indicator species recorded was at 7.8\%, and soil charcoal had an importance of $3.4 \%$. Many predictor variables were relevant to the model, including Indian cucumber root presence, blueberry presence, and soil charcoal presence. The absence of maple was also revealed to be a relevant predictor for treatment type, with a higher incidence of overstory maple on off-site areas than archaeological sites.

Trees per hectare and landscape variables are indicated as having the highest importance in predicting treatment type (archaeological or off-site). This may indicate that using geotopographical characteristics in conjunction with vegetation would be the best predictor of the potential for cultural resources. Fort Drum Cultural Resources Management personnel have employed a GIS model with some success in predicting site locations (Ft Drum GIS personnel, Terrace Model) [65,66]. This model used a topographic index that predicted the location of what can be characterized as terrace or bench sites, areas of minimal slope occurring above the elevation of stream valleys. With the relative success of this model, factors that influence or are influenced by topography should be important. However the model used by Drum CRM was used to broadly identify areas of potential cultural resources of any time period, while this study is concerned with a particular group of Native Americans during a relatively constrained time period.

At Quantico, landscape-level geomorphological factors were again the most important factors predicting the response variable of treatment type. Importance values for plot-level trees per hectare, slope, aspect, elevation, and soil series ranged from $23.1 \%$ (soil series) to $16.1 \%$ (trees per hectare; Figure 2). Decreased tree densities on archaeological sites (Table 5) underpin the importance of stems per hectare in locating cultural landscapes. Importance values of the presence/absence of vegetation species ranged from 13.3 (white oak, a significant indicator species) to -2.4 (raspberry). Importantindicator species occurrences and total indicator occurrences had relatively low importance values ( 0.3 to $5.6 \%$ ), however total indicator species present and importance mast-producing tree species present did have importance values above $2.4 \%$, indicating their relevance to prediction of treatment type (archaeological or off-site area). Soil charcoal was a somewhat better predictor of treatment, with an importance value of $9.0 \%$. As at Fort Drum, geological and topographical variables were the most important, leading to similar hypotheses regarding the relationship between these predictor variables and archaeological resources across the broader landscape of MCB Quantico. However at MCB Quantico, white oak appears to show importance values fairly close to landscape position variables, which is a very significant finding for this research.

The presence of white oak had the highest importance among the vegetation presence/absence variables as a predictor of treatment type. This is consistent with observations by John Haynes, former Cultural Resources Manager for MCB Quantico, that archaeological sites often seem to be located in areas of high white oak importance in the overstory (personal communication). Indeed, cultural sites in certain areas of the base have high white oak importance (Table 5) which indicates that this trend is correlated with archaeological significance. White oak is a calciphile and thus is most often found in areas of specific soil chemistry, often characteristic of topographical positions such as valley, bench and cove sites [67]. Soil testing of sites containing higher incidence of white oak in the overstory indicated increased calcium and magnesium (parts per million), and slightly higher $\mathrm{pH}$, and soil series was also a good predictor of treatment type (with an importance value of $23.1 \%$ ). These lines of evidence suggest a correlative relationship between soil type, white oak presence, and archaeological resources.

Qualitative consideration of the presence or absence of certain indicator species was a very useful analysis, when trends in vegetation on archaeological sites or off-site areas were not fully or accurately characterized by traditional quantitative methods. An example is the distribution of chenopodium (or lambsquarters) at Fort Drum, a native grain and early cultigen in the Eastern Agricultural Complex [68,41]. At Fort Drum, chenopodium is found in open areas on archaeological sites and off-site areas on the sandy glacial outwash moraine, as well as areas to the east of the moraine. These areas were not captured in many vegetation plots because they often occur in more open sites and on the periphery of archaeological sites. However, this species was noted in reconnaissance surveys of six important archaeological sites, in vegetation surveys of two important sites, and in the surrounding areas of the open, oak savanna type vegetation on the sandy glacial moraine.

Another trend noted at Fort Drum was the characteristic of sparse understory vegetation on archaeological sites, especially those where artifacts such as post molds and hearths were discovered (these features indicate structures and thus semilong-term habitation). This was most notable at "Camp Drum 1", the site of a St. Lawrence Iroquoian village during the Late Woodland Time Period (Fort Drum Cultural Resources Management). Native American village sites would have been good defensible positions, within close proximity to fresh water, and on dry, well-drained, and level ground. These villages were inhabited for some period of time before resources in the surrounding area were likely depleted; then the village would be moved to another location [9]. These areas were inhabited by Native Americans in a rotation, and then by Europeans for their defensibility, proximity to freshwater, and other desirable settlement characteristics (e.g., cleared, fertile areas). The results of this study and others suggest that continuation of use, such as for agriculture or timbering, of these areas maintained them in a pre-European vegetation state $[69,70]$. Also noted were lower overstory tree densities on archaeological sites both at Fort Drum and Quantico, further supporting this conclusion. 
At Fort Drum, archaeological sites are most prevalent in areas of sandy, well-drained soil, especially the sand plains of the glacial moraine. These characteristics make it attractive for habitation and resource-gathering, including abundant sources of food, well-drained soils, and relatively clear understory. Therefore, a specific species composition of several key species (oak, pine, blueberry, and serviceberry) is prevalent on many of the archaeological sites on Fort Drum. This composition is indicated as being important in both overstory comparison and classification tree modeling, and is correlated with soils and topography and well as archaeological resources. Similarly, at MCB Quantico many Late Woodland cultural sites are found with a higher incidence of white oak, and on soils of a particular type supporting vegetation associated with rich, mesic areas. Although the trend of white oak presence on archaeological sites is not supported by all sites located on Quantico, many of the important sites where actual relatively long-term habitation was expected to have occurred do uphold the pattern. Other archaeological sites on MCB Quantico tended to be found in areas of more xeric soils and composition, indicated by increased importance of species such as chestnut oak. These trends could provide information to cultural resources personnel on site distribution across a broad landscape, utilizing both geotopographical characteristics and indicator vegetation to elucidate settlement patterns versus seasonal use.

A potential factor influencing these results is the effect of broad landscape level practices such as understory burning, and the creation of a "sphere of influence" surrounding areas of high anthropological significance. One of the main factors of Native American land use, broadcast understory burning, has been shown to be a very important tool associated with human habitation $[4,16,28]$. If, as many researchers suggest, this was the driving factor in the compositional change of forests in the preEuropean settlement landscape [6], it may be that the changes affected were broad and thus reduced site-level differences between archaeological sites and adjacent off-site areas.

\section{Conclusion}

At Fort Drum, New York, and MCB Quantico, Virginia, higher incidence of certain indicator species and soil charcoal can be correlated with cultural sites. This trend could be typified by one species (such as white oak at MCB Quantico), or it can be a grouping of several species (such as the species association that dominates the sandy glacial moraine at Fort Drum). In areas of fairly ubiquitous usage of the landscape or a particular feature of the landscape, such as the riparian areas and bluffs above brackish waterways of the Cheatham Annex, Virginia, variation in the distribution of fire-dependent species and soil charcoal can aid in identifying what particular type of Native American usage the land may have experienced (e.g., habitation, gathering and processing of plant food resources, gathering of shellfish, etc). Decreased tree densities on archaeological sites at Fort Drum and MCB Quantico also indicate that in these landscapes, areas of sparser overstory should be prioritized for archaeological testing.

Pinpointing a combination of geological, soil, topographical, and vegetation characteristics that are typical of Late Woodland and Mississippian Time Period Native American cultural sites could allow Cultural Resources Management programs on military lands to more efficiently identify landscapes where the probability of locating archaeological features is greater. Analysis of these features may also allow CRM personnel to more accurately characterize the types of land use or activities that occurred on these sites. Soil charcoal analysis could serve as a rapid method of determining fire history during the time period of interest. Surveys of vegetation could be integrated into testing strategies either before or after archaeological site discovery, to both locate and prioritize landscapes of particular interest, or further elucidate what kinds of activities may have been occurring following the discovery of a site. The presence of white oak in the area of MCB Quantico can be viewed as an indicator of past Native American land use and habitation, while pyrogenic communities such as oak-pine-blueberry at Fort Drum, are key communities that indicate high probability of the presence of significant cultural resources. Where these species exist in combination with other utilized species and decreased tree densities, the likelihood of discovery of cultural resources increases greatly.

\section{Acknowledgement}

This research was funded by Department of Defense Legacy Resource Management Program grant 10-416 with Dr. Laurie Rush as a co-principal investigator and research facilitator.

\section{References}

1. Denevan WM (1992) The Pristine Myth: The landscape of the Americas in 1492. Annals of the Association of American Geographers 82(3): 369-385.

2. Anderson MK, Moratto MJ (1996) Native American land-use practices and ecological impacts. Sierra Nevada Ecosystem Project Final Report to Congress University of California Davis. Pages 2(9): 187-206.

3. Day GM (1953) The Indian as an ecological factor in the northeastern forest. Ecology 34(2): 329- 346.

4. Pyne SJ (1983) Indian fires. Natural History 2: 6-11.

5. Delcourt HR (1987) The impact of prehistoric agriculture and land occupation on natural vegetation. Trends Ecol Evol 2(2): 39-44.

6. Abrams MD, Nowacki G J (2008) Native Americans as active and passive promoters of mast and fruit trees in the eastern USA. The Holocene 18(7): 1123-1137.

7. Russell EWB (1983) Indian-set fires in the forests of the northeastern United States. Ecology 64(1): 78-88.

8. Black BA, Abrams MD (2001) Influences of Native Americans and surveyor biases on metes and bounds witness-tree distribution. Ecology 82(9): 2574-2586.

9. Trigger BG (1978) Handbook of North American Indians -Northeast Volume 15. Sturtevant WC editor. Smithsonian Institution Washington DC. 


\section{Global Journal of Archaeology \& Anthropology}

10. Doolittle WE (1992) Agriculture in North America on the eve of Contact: A reassessment. Annals of the Association of American Geographers 82(3): 386-401.

11. Mrozowski SA (1994) The discovery of a Native American cornfield on Cape Cod. Archaeology of Eastern North America 22: 47-62.

12. Clark JS, Royall PD (1995) Transformation of a northern hardwood forest by aboriginal (Iroquois) fire: Charcoal evidence from Crawford Lake Ontario Canada. The Holocene 5(1): 1-9.

13. Delcourt PA, Delcourt HR, Ison CR, Sharp WE, Gremlin KJ (1998) Prehistoric human use of fire the Eastern Agricultural Complex and Appalachian oak-chestnut forests: Pale ecology of Cliff Palace Pond Kentucky. American Antiquity 63(2): 263-278.

14. MacDougall A (2003) Did Native Americans influence the northward migration of plants during the Holocene? Journal of Biogeography 30(5): 633-647.

15. Fritz GJ (1990) Multiple pathways to farming in precontact eastern North America. Journal of World Prehistory 4(4): 387-435.

16. Patterson WA, Sass Man KE (1988) Indian fires in the prehistory of New England. In Holocene Human Ecology in Northeastern North America Nicholas, G P editor Plenum Press New York New York, USA. pp. 107-135.

17. Bamann S, Kuhn R, Molnar J, Snow D (1992) Iroquoian Archaeology. Annual Review of Anthropology 21: 435-460.

18. Custer JF (1994) Current archaeological research in the Middle Atlantic region of the eastern United States. Journal of Archaeological Research 2(4): 329-360.

19. Pihl RH, Monckton SG, Robertson DA, Williamson RF (2008) Settlement and subsistence change in the turn of the first millennium: The view from the In Current Northeast Paleoethnobotany New York, USA, pp. 151-172.

20. Smith BD (1989) Origins of agriculture in eastern North America. Science 246(4937): 1566-1571.

21. Peterson RN, Moore JN, Ballington JR (1991) Genetic Resources of Temperate Fruit and Nut Crops. Acta Horticulturae 290: 567-600.

22. Munson PJ (1986) Hickory silviculture: A subsistence revolution in the prehistory of eastern North America in Emergent Horticultural Economies of Eastern Woodlands Keegan WF editor. Southern Illinois University Carbondale Illinois, USA, p. 1-20.

23. Wykoff MW (1991) Black walnut on Iroquoian landscapes. Northeastern Indian Quarterly 4: 4-17.

24. Loeb RE(1998) Evidence of prehistoric corn (Zea mays) and hickory (Carya spp.) planting in New York City: Vegetation history of Hunter Island, Bronx County, New York. Journal of the Torrey Botanical Society 125(1): 74-86.

25. Abrams MD (1992) Fire and the development of oak forests. Bioscience 42(5): 346-353.

26. Foster HT, Black B, Abrams MD (2004) A witness tree analysis of the effects of Native American Indians on the pre-European settlement forests in east-central Alabama. Human Ecology 32(1): 27-47.

27. Downey CH, Downey JR (1989) An unusual oak savanna in northeastern Wisconsin: The effect of Indian-caused fire. American Midland Naturalist 122(1): 103-113.

28. Whitney GG (1994) From Coastal Wilderness to Fruited Plain. Cambridge University Press Cambridge, UK.

29. Delcourt HR, Delcourt PA (1997) Pre-Columbian Native American use of fire on southern Appalachian landscapes. Conservation Biology 11(4): 1010-1014.
30. Sutherland EK, Hutchinson TF (2003) Characteristics of mixed-oak forest ecosystems in southern Ohio prior to the reintroduction of fire. USDA Forest Service General Technical Report NE-299.

31. Black BA, Ruffner CM, Abrams MD (2006) Native American influences on the forest composition of the Allegheny Plateau northwest Pennsylvania. Canadian Journal of Forest Research 36(5): 1266-1275.

32. Guyette R, Muzika RM, Dey DC (2002) Dynamics of an anthropogenic fire regime.Ecosystems 5(5): 472-486.

33. Lorimer CG, White AS (2003) Scale and frequency of natural disturbances in the northeastern US: Implications for early successional forest habitats and regional age distributions. Forest Ecology and Management 185: 41-64.

34. Kay CE, Masters RE, Galley KEM (2007) Are lightning fires unnatural? A comparison of aboriginal and lightning ignition rates in the United States. In Proceedings of the 23rd Tall Timbers Fire Ecology Conference: Fire in Grassland and Shrubland Ecosystems. Tall Timbers Research Station Tallahassee Florida. Pages 16-28.

35. Frost CC, Pruden TL, Brennan LA (1998) Presettlement fire frequency regimes of the United States: A first approximation. In Fire in Ecosystem Management: Shifting the paradigm from suppression to prescription. Tall Timbers Fire Ecology Conference Proceeding, number 20. p. 70-81.

36. Foster DR, Motzkin G, Slater B (1998) Land-use history as long-term broad-scale disturbances: Regional forest dynamics in central New England. Ecosystems 1(1): 96-119.

37. Dey DC, Guyette RP (2000) Anthropogenic fire history and red oak forests in south-central Ontario. The Forestry Chronicle 76(2): 339347.

38. Lorimer CG (1984) Development of the red maple understory in northeastern oak forests. Forest Science 30: 3-22.

39. Abrams MD, Nowacki GJ (1992) Historical variation in fire oak recruitment and post- logging accelerated succession in central Pennsylvania. Bulletin of the Torrey Botanical Club 119(1): 19-28.

40. Lewandowski S, Diohe'ko (1987) the Three Sisters in Seneca life: Implications for a native agriculture in the Finger Lakes region of New York State. Agriculture and Human Values 4(2): 76-93.

41. Smith BD (2006) Eastern North America as an independent center of plant domestication.Proceedings of the National Academy of Sciences 103(33): 12223-12228.

42. Wandsnider L (1997) The roasted and the boiled: Food composition and heat treatment with special emphasis on pit-hearth cooking. Journal of Anthropological Archaeology 16: 1-48.

43. Scarry CM, Scarry JF (2005) Native American 'garden agriculture' in southeastern North America. World Archaeology 37(2): 259-274.

44. Marks PL, Gardescu S, Seischab FK (1992) Late Eighteenth Century vegetation of central and western New York State on the basis of original land survey records.

45. Whitney G, De Cant JP (2003) Physical and historical determinants of the pre and post- settlement forests of northwestern Pennsylvania. Canadian Journal of Forest Research 33(9): 1683-1697.

46. Snow DR (1996) Mohawk demography and the effects of exogenous epidemics on American Indian populations. Journal of Anthropological Arch biology 15(2): 160-182.

47. Smith J (2003) A True Relation of Occurrences and Accidents in Virginia, In Travels and works of Captain John Smith President of Virginia and Admiral of New England 1580-1631.

48. Fuller JL, Foster DR, McLachlan JS, Drake N (1998) Impact of human activity on regional forest composition and dynamics in central New England. Ecosystems 1(1): 76-95. 
49. Rhemtulla JM, Mladenoff DJ, Clayton MK (2007) Regional land-cover conversion in the U S upper Midwest: Magnitude of change and limited recovery Landscape Ecology 22(S1): 57-75.

50. Schulte LA, Mladenoff DJ, Crow TR, Merric LC, Cleland DT, et al. (2007) Homogenization of northern U.S. Great Lakes forests due to land use. Landscape Ecology 22(7): 1089-1103.

51. Waselkov GA (1987) Shellfish gathering and shell midden archaeology. Advances in Archaeological Method and Theory 10(1987): 93-210.

52. Tryon EH (1948) Effect of charcoal on certain physical chemical and biological properties of forest soils. Ecological Monographs 18(1): 81115.

53. Ohlson M, Tryterud E (2000) Interpretation of the charcoal record in forest soils: Forest fires and their production and deposition of macroscopic charcoal. The Holocene 10(4): 519-525.

54. Gavin DG, Brubaker LB, Lertzman KP (2003) Holocene fire history of a coastal temperate rain forest based on soil charcoal radiocarbon dates. Ecology 84(1): 186-201.

55. R Core Team (2012) R: A Language and Environment for Statistical Computing. R Foundation for Statistical Computing, Vienna, Austria.

56. Breiman L (2001) Random Forests. Machine Learning 45(1): 5-32.

57. Liaw A, Wiener M (2002) Classification and regression by randomForest. R News Loeb Evidence of prehistoric corn (Zea mays) and hickory (Carya spp.) planting in2(3): 18-22.

58. Rogers ES (1965) The dugout canoe in Ontario. American Antiquity 30(4): 454-459.

59. Burns RM, Honkala BH (1990) Silvics of North America: 1. Conifers 2. Hardwoods. Agricultural Handbook 654 US Department of Agriculture Forest Service Washington. DC.

60. Arnason T, Habra RJ, Johns T (1981) Use of plants for food and medicine by native peoples of eastern Canada. Canadian Journal of Botany 59(11): 2189-2325.

61. Hummer KE (2013) Manna in winter: Indigenous Americans huckleberries and blueberries. HortScience 48(4): 413-417.

62. Havard V (1895) Food plants of the North American Indians. Bulletin of the Torrey Botanical Club 22(3): 98-123.

63. Strobl C, Malley J, Tutz G (2009) An introduction to recursive partitioning Rational application and characteristics of classification and regression trees bagging and random forests. Psychological Methods 14(4): 323-348.

64. Shih S (2011) Random forests for classification trees and categorical dependent variables An informal quick start $\mathrm{R}$ guide. Stanford University Stanford Connecticutt.

65.Zeidler JA (2001) Dynamic modeling of landscape evolution and archaeological site distributions: A three-dimensional approach. SERDP Project CS-1130.

66. Crawford GW, Smith DG (2002) Early Late Woodland in southern Ontario: An update In Northeast Subsistence-Settlement Change: A D 700-1300.

67. Abrams MD (2003) Where has all the white oak gone? Bioscience 53(10): 927-939.

68. Smith BD (1984) Chenopodium as a prehistoric domesticate in eastern North America: Evidence from Russell Cave Alabama. Science 226(4671): 165-167.

69. Black BA, Abrams MD (2001) Analysis of temporal variation and species-site relationships of witness tree data in southeastern Pennsylvania. Canadian Journal of Forest Research 31(3): 419-429.

70. Foster DR, Motzkin G (2003) Interpreting and conserving the openland habitats of coastal New England: Insights from landscape history. Forest Ecology and Management 185: 127-150.

\section{Your next submission with Juniper Publishers will reach you the below assets}

- Quality Editorial service

- Swift Peer Review

- Reprints availability

- E-prints Service

- Manuscript Podcast for convenient understanding

- Global attainment for your research

- Manuscript accessibility in different formats

( Pdf, E-pub, Full Text, Audio)

- Unceasing customer service

Track the below URL for one-step submission https://juniperpublishers.com/online-submission.php 